\title{
Acute Hepatitis C in Persons Infected with the Human IMMUNODEFICIENCY VIRUS (HIV): The "Real-Life SetTing” Proves the Concept
}

\author{
M. Obermeier ${ }^{1 *}$, P. Ingiliz ${ }^{1 *}$, L. Weitner ${ }^{2}$, C. Cordes 3 , A. Moll, B. Hintsche ${ }^{5}$, F. Schlote ${ }^{6}$, S. Koeppe \\ S. Christensen ${ }^{8}$, C. Mayr ${ }^{9}$, A. Baumgarten ${ }^{1}$
}

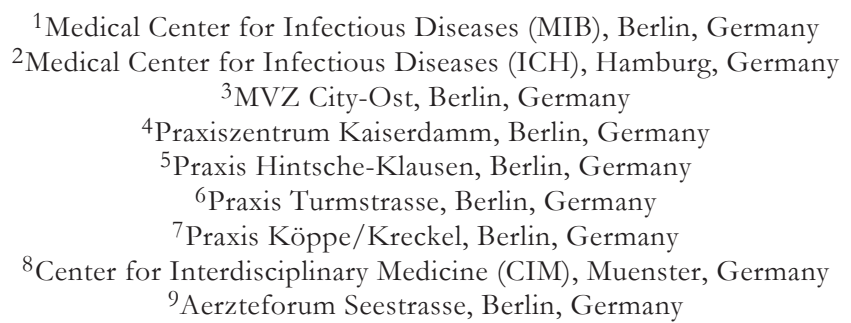

\section{Abstract}

Objectives: Outbreaks of sexually transmitted acute $\mathrm{HCV}$ infection have been described recently in several cities in the western world. The epidemic affects mainly MSM who are coinfected with HIV and is supposably linked to certain sexual risk practices. Here, we compared our findings with current knowledge and recommendations.

Methods: HIV-positive patients with the diagnosis of acute HCV infection were included in the retrospective analysis. The patients came from outpatient infectious disease centers in northern German cities. We looked at markers of HIV and HCV infection and compared patients who received treatment and those who did not. Treated patients were followed up to 72 weeks.

Results: Three hundred nineteen HIV-positive patients with the diagnosis of acute hepatitis $\mathrm{C}$ between 2001 and 2008 and were included in the analysis. All patients were male, $315(99 \%)$ patients were of caucasian origin, $296(93 \%)$ declared homosexual contacts as a risk factor for $\mathrm{HCV}$ infection, intravenous drug use was declared in $3(1 \%)$ cases. Median age at $\mathrm{HCV}$ diagnosis was 40 years (range 20-69 years). Median $\mathrm{HCV}$ viral load was $1.2 \times 10^{6} \mathrm{IU} / \mathrm{mL}, 222 \mathrm{pa}-$ tients $(70 \%)$ had HCV genotype 1, 59 (18\%) genotype 4. The median time of HIV infection was 5.5 years (range 0 to 22.4 years). Median HIV viral load was 110 copies $/ \mathrm{mL}$ (range 25 to $10 \times 10^{6}$ copies $/ \mathrm{mL}$ ). The median CD 4 count was 461 cells $/ \mathrm{mm}^{3}$ (range 551331 cells $/ \mathrm{mm}^{3}$ ). Two hundred and fourty-six patients $(77 \%)$ received anti-HCV treatment, and 175 (55\%) had completed therapy by the time of the analysis. Median treatment duration was 33 weeks (IQR 24.149.9). 93 of the 175 treated patients (53\%) reached a sustained virological response (SVR). In the multivariate analysis, ART at diagnosis, HCV RNA drop at

*Both authors contributed equally. week 12, hemoglobin levels and higher platelets were associated with SVR. Treatment duration was significantly higher in the SVR group (40.6 weeks vs 26.6 weeks, $\mathrm{p}<0.0001)$. Seventy-three patients $(23 \%) \mathrm{did}$ not receive anti-HCV treatment. In 19 of the untreated patients $(26 \%)$ the hepatitis $C$ virus was cleared spontaneously.

Conclusions: Our findings confirm that acute hepatitis $\mathrm{C}$ in HIV infected patients affects mainly MSM who acquire HCV sexually. Patients had a short duration of HIV infection and a stable immunological situation. In this real-life setting from urban regions in northern Germany, treatment rates appear to be high and effective.

Key words: Acute hepatitis C, HIV, interferon, SVR, spontaneous clearance

\section{INTRODUCTION}

An outbreak of sexually transmitted acute hepatitis $C$ virus (HCV) infection has been documented in large cities in Europe, the United States and Australia during the past years [1-7]. The epidemic, that mainly affects men who have sex with men (MSM) who are coinfected with the human immunodeficiency virus (HIV), seems to be linked to a certain sexual risk behavior within parts of the homosexual community and is suspected to be spread through a "sexual network" of men frequenting the same clubs and "sex parties" in different urban regions of the world. Whereas the transmission of $\mathrm{HCV}$ in this part of the world has been historically associated with parenteral infection such as intravenous drug use in the majority of cases, permucosal trauma seems to be the main risk factor in these "new" patients [8, 9].

Since the introduction of combination antiretroviral therapy (cART) has substantially prolonged survival [10], liver disease such as chronic hepatitis $C$ is one of the major factors for mortality and morbidity 
Table 1. Baseline characteristics of the $319 \mathrm{HIV}$ patients with acute hepatitis $\mathrm{C}^{\mathbf{a}}$.

\begin{tabular}{|c|c|}
\hline Age [years] (range) & $40(20-69)$ \\
\hline Sex, male $[\%]$ & 100 \\
\hline HCV transmission risk MSM, n (\%) & $296(93)$ \\
\hline $\begin{array}{l}\text { Time since HIV infection [years] } \\
\text { (range) }\end{array}$ & $5.5(0-22.4)$ \\
\hline CD4 count [cells / $\mu 1]$ (range) & $461(55-1331)$ \\
\hline HIV viral load [copies/mL] (range) & $110\left(50-10 \times 10^{6}\right)$ \\
\hline cART, n (\%) & $200(63)$ \\
\hline CDC stage $\mathrm{C}, \mathrm{n}(\%)$ & $59(18)$ \\
\hline HCV RNA [IU/mL] (range) & $1.2 \times 10^{6}\left(33-676 \times 10^{6}\right)$ \\
\hline HCV genotype $1, \mathrm{n}(\%)$ & $222(70)$ \\
\hline $\begin{array}{l}\text { Maximum ALT level at diagnosis }{ }^{b} \\
\text { [IU/mL] (range) }\end{array}$ & $420(19-4217)$ \\
\hline $\begin{array}{l}\text { Symptomatic hepatitis, as indicated } \\
\text { by physician, n (\%) }\end{array}$ & $83(26)$ \\
\hline Time to treatment ${ }^{c}$, weeks (IQR) & $12.6(4.7-24.4)$ \\
\hline Duration of therapy, weeks (IQR) & $33(24.1-49.9)$ \\
\hline
\end{tabular}

a values are given as median unless otherwise indicated. b Maximum median alanin aminotransferase (ALT) level is the maximum increase in ALT measured at the time of diagnosis.

'Time to treatment is the time between diagnosis and first dose given. MSM, men who have sex with men. CDC, Center for disease control and prevention.

in the HIV infected population [11]. Consequently, the assumed sexual spread of HCV may have a serious clinical impact for HIV positive MSM.

HIV coinfection seems to lead to a lower rate of spontaneous clearance in acute HCV infection, a faster fibrosis progression in chronic hepatitis $C$ and reduces response rates to standard treatment regimens with pegylated interferon (PegIFN) and Ribavirin (RBV) [12-15] compared to the HCV monoinfected population.

Several groups from England, France, Germany, Australia, the United States and the Netherlands have recently published their data on the nature of the epidemic and treatment outcomes in HIV-acute HCVcoinfected patients. Sustained virological response rates in these studies ranged between 59 and $80 \%$ of the treated patients, depending on genotype and treatment duration [16]. Interestingly, the results from an observational European multicentre cohort showed no influence of $\mathrm{HCV}$ genotype or HCV viral load on overall SVR rates of $62 \%$ [17]. Several issues such as the type of pegylated interferon used, a benefit of additional ribavirin or the optimal starting point for treatment and treatment duration remain still unsolved. However, prospective trials have unfortunately not yet been undertaken and are urgently needed to answer these questions.

The aim of this retrospective analysis was to review treatment decisions and outcomes in HIV positive patients with acute hepatitis $C$ in a routine clinical setting. Moreover, we tried to compare these findings with current knowledge and recommendations.

\section{PATIENTS AND Methods}

Consecutive patients coinfected with HIV and acute hepatitis $\mathrm{C}$ were included in this retrospective analysis. The patients came from outpatient infectious disease centers in northern German cities. These centers care for approximately $9000 \mathrm{HIV}$ positive patients annually, of whom about 1350 (15\%) are HCV co-infected. Acute hepatitis $\mathrm{C}$ was defined as a positive $\mathrm{HCV}$ polymerase chain reaction (PCR), and at least two conditions out of the following being confirmed: HCV seroconversion within the last 6 months, an increase in serum ALT of more than $350 \mathrm{IU} / \mathrm{mL}$ or a suspected risk event in the past 6 months before diagnosis.

Data was collected by chart review. We looked at demographic factors, risk factors for HCV infection, HCV viral load and HIV surrogate markers as well as liver function tests at the time of diagnosis of acute $\mathrm{HCV}$ infection. The history of HIV infection, the current treatment for HIV infection, and the number of patients in stage $\mathrm{C} 3$ according to the classification of the Centre for Disease control (CDC, Atlanta, USA) [18] was taken into account.

Furthermore, the physician's clinical impression (symptomatic, asymptomatic) at the time of diagnosis of acute HCV was included in the analysis.

The patients were then divided into two groups, a treated group and an untreated group. Treated patients received at least one dose of either pegylated interferon $\alpha-2$ a $(180 \mu \mathrm{g}$ per week subcutaneously (s.c.)) or pegylated interferon $\alpha-2 b(1.5 \mathrm{mg} / \mathrm{kg}$ body weight per week s.c.) with or without weight-based ribavirin (800$1200 \mathrm{mg} / \mathrm{d})$.

Treated patients were followed with the same laboratory markers mentioned above at week 4, 12, 24 and 48 of treatment and during a 24 -week follow up period after the last dose of interferon to define SVR. Untreated patients were followed up to observe spontaneous clearance.

Laboratory parameters were measured locally. HCV-PCR was performed with ultrasensitive assays with a lower limit of quantification (LLQ) between 15 $\mathrm{IU} / \mathrm{mL}$ and $600 \mathrm{IU} / \mathrm{ml}$, as detection limits changed over the time of the observation period.

Statistical analysis was performed using "R" (The R Foundation for Statistical Computing, Vienna, Austria). Student's t-test was used to compare groups, a pvalue below $5 \%$ was considered statistically significant. A multivariate analysis by logistic regression was conducted to define the odd's ratios of SVR.

\section{RESULTS}

A total of three hundred nineteen HIV-positive patients met the criteria for acute hepatitis $\mathrm{C}$ between 2001 and 2008 and were included in the analysis. Patients came from ten different ambulatory care centers in 4 different cities in Germany, however, 264 patients $(83 \%)$ were diagnosed in Berlin. All patients were male, $315(99 \%)$ patients were of caucasian origin, 296 $(93 \%)$ declared homosexual contacts as the only possible risk factor for $\mathrm{HCV}$ infection, intravenous drug use was declared in $3(1 \%)$ cases and for 21 patients 
Table 2. Multiple logistic regression of factors associated with SVR.

\begin{tabular}{|c|c|c|c|c|}
\hline & $\mathrm{p}$ value & Odds-Ratio & CI 2,5 & CI 97,5 \\
\hline HCV RNA week 0 & 0.1151 & 1.00 & 1.00 & 1.00 \\
\hline HCV-RNA decline week 4 & 0.1767 & 2.11 & 0.83 & 8.99 \\
\hline HCV-RNA decline week 12 & 0.0178 & 2.85 & 1.35 & 8.38 \\
\hline$A L T$ max $b$ & 0.2786 & 1.00 & 1.00 & 1.01 \\
\hline $\mathrm{Hb}$ week $0^{\mathrm{a}}$ & 0.07 & 0.20 & 0.02 & 0.79 \\
\hline Hb week 4 & 0.1665 & 0.46 & 0.13 & 1.28 \\
\hline Hb week 12 & 0.024 & 4.71 & 1.44 & 23.30 \\
\hline HIV viral load week 0 & 0.8572 & 1.00 & 1.00 & 1.00 \\
\hline ALT week 0 & 0.8024 & 1.00 & 0.99 & 1.00 \\
\hline GGT week 0 & 0.8421 & 1.00 & 0.99 & 1.01 \\
\hline Platelets week 0 & 0.0337 & 0.96 & 0.91 & 0.99 \\
\hline ART vs no ART at diagnosis & 0.0338 & 3.94 & 2.83 & 9.84 \\
\hline CD4 cell count week 0 & 0.2988 & 1.00 & 1.00 & 1.01 \\
\hline
\end{tabular}

${ }^{a}$ week refers to anti-HCV treatment week, ${ }^{b}$ Maximum median alanin aminotransferase (ALT) level is the maximum increase in ALT measured at the time of diagnosis. Hb, hemoglobin, ART, antiretroviral treatment

$(6 \%)$ no risk factor was indicated. Median age at $\mathrm{HCV}$ diagnosis was 40 years (range 20-69 years).

Median HCV viral load was 1.2 × $10^{6} \mathrm{IU} / \mathrm{mL}$. The HCV genotype distribution was as follows: 222 patients $(70 \%)$ had genotype $1,7(2 \%)$ genotype 2,26 (8\%) genotype 3, $59(18 \%)$ genotype 4 , and in $5(2 \%)$ patients the HCV genotype was not indicated. The median maximum alanin aminotransferse (ALT) level at diagnosis was $420 \mathrm{IU} / \mathrm{mL}$ (range 19 to 4217). The median bilirubin level was $1.2 \mathrm{mg} / \mathrm{dL}$ (range 0.1 to $35)$. In 83 cases $(26 \%)$ patients were indicated as symptomatic by their physician.

The median time of HIV infection was 5.5 years (range 0 to 22.4 years). Two hundred patients (63\%) were on cART or started cART at the time of HCV diagnosis, 26 patients had a history of antiretroviral therapy but were currently not treated, 79 patients were naïve for HIV therapy, and in 13 cases no data on HIV treatment could be retrieved. Overall, 105 patients $(33 \%)$ were not treated for HIV infection. 59 $(18 \%)$ patients were classified as CDC stage C3, in 4 cases this information was not available. Patients on cART did not differ from untreated patients in terms of ALT levels, bilirubin levels, absolute CD 4 lymphocyte count. HCV viral load was higher in the noncART group $\left(1.8 \times 10^{6} \mathrm{iU} / \mathrm{mL}\right.$ vs $\left.1.0 \times 10^{6} \mathrm{iU} / \mathrm{mL}\right)$.

Median HIV viral load was 110 copies/mL (range 25 to $10 \times 10^{6}$ copies $/ \mathrm{mL}$ ). The median CD 4 lymphocyte count was 461 cells $/ \mathrm{mm}^{3}$ (range 55-1331 cells $/ \mathrm{mm}^{3}$ ), median CD4 percentage was $24 \%$ (range 3 to 64). Baseline characteristics are summarized in Table 1.

Two hundred and fourty-six patients (77\%) received anti-HCV treatment, and $175(55 \%)$ had completed therapy by the time of the analysis. All treated patients received either pegylated interferon $\alpha-2$ a or $\alpha-2 b, 240$ patients $(91 \%$ of treated patients) received additional ribavirin.

The median time from diagnosis to initiation of treatment was 12.6 weeks (IQR 4.7-24.4). Median treatment duration was 33 weeks (IQR 24.1-49.9). 93 of the 175 treated patients $(53 \%)$ met the SVR criteria (HCV viral load undetectable 24 weeks after end of therapy), $42(24 \%)$ did not and in another 40 patients the follow-up period was not yet terminated or data was missing. In the on-treatment analysis, $69 \%$ of the patients fulfilled the criteria for SVR. SVR was associated with an earlier onset of anti-HCV treatment after diagnosis (9.6 weeks vs 11 weeks), but this was not statistically significant. In multiple logistic regression a viral load drop at week 12, drop in hemoglobin levels at week 12, higher platelets and cART at the time of $\mathrm{HCV}$ diagnosis turned out statistically significant (Table 2). A rapid virological response (RVR, HCV RNA undetectable at week 4) was reached in 31\% of patients. RVR predicted SVR in 87\%. At week 12, 108 patients had undetectable HCV RNA (early virological response - EVR) and 70 patients $(65 \%)$ reached an SVR. Of the 38 patients that did not fulfill the criterion of an EVR, only 6 (15\%) finally had an SVR. Treatment duration was significantly higher in the SVR group (40.6 weeks vs 26.6 weeks, $\mathrm{p}<0.0001$ ). Moreover, we saw a trend towards lower HCV PCR levels at diagnosis and the achievement of SVR, however, this difference was not significant. No difference was seen in maximum GPT levels before treatment between patients with or without SVR.

Treatment was interrupted before week 24 in 30 patients, in 15 cases due to non-response or virological breakthrough, in the other cases due to side effects. Seventy-three patients $(23 \%)$ did not receive anti-HCV treatment. In 19 of the untreated patients $(26 \%)$ the hepatitis $\mathrm{C}$ virus was cleared spontaneously. The median CD4 cell count in these patients was $461 / \mathrm{mm}^{3}$, median bilirubin was $2.15 \mathrm{mg} / \mathrm{dL}(\mathrm{p}=0.03)$ and the median GPT level was $744 \mathrm{IU} / \mathrm{mL}$. In untreated patients without spontaneous clearance the median GPT level was $339 \mathrm{IU} / \mathrm{mL}$ and the median bilirubin level was $1 \mathrm{mg} / \mathrm{dL}$. These differences were not statistically significant. 


\section{DISCUSSION}

This retrospective analysis could give an interesting insight on the "real life" management of acute hepatitis $\mathrm{C}$ in HIV coinfected patients. Our patients were mainly middle-aged men and nearly all of them indicated homosexual contacts as the assumed risk factor for acquiring HCV. This goes in line with the findings of other work groups dealing with the same issue $[5,18$ 20]. All of our patients were diagnosed in German urban areas with Berlin appearing to be the hotspot of transmission.

Our patients were HIV-positive and had a relatively stable immunological situation with a median CD4 count at 461 cells $/ \mathrm{mm}^{3}$ and no more than 9 patients had a CD4 count below 200 cells $/ \mathrm{mm}^{3}$ at the time of hepatitis C diagnosis. Only 18\% of our patients had a history of an AIDS-defining event. Moreover, the median time of HIV infection was relatively low (about 5 years). This confirms findings from other cohorts [17] and one may conclude that an impaired immune system is not a necessary risk factor to acquire hepatitis $\mathrm{C}$ sexually. Although it has been postulated that HIV coinfection might facilitate HCV transmission by increasing both viral infectiousness because of higher HCV viral loads in serum and semen and viral susceptibility through impaired immunologic control of HCV [20, 21] no proof of this concept has yet been found. This leads to the thesis that behavioral risk factors such as "serosorting sex parties" and traumatic sexual practices are necessary for the sexual transmission [9]. Moreover, rare cases of sexual HCV transmission in HIV negative MSM have been described [22]. It is noteworthy that HIV infected patients are more likely to be diagnosed with concomitant diseases due to regular medical check-ups, which is also true for the diagnosis of hepatitis C. However, in several cohorts it has been shown recently that acute sexually transmitted hepatitis $\mathrm{C}$ rarely occurs in HIV-negative individuals and also not in $\mathrm{HIV}$-infected women [2326].

About one third of our patients was not treated for their HIV infection and several patients started HIV treatment when diagnosed with acute $\mathrm{HCV}$ infection. Considering the fact that $\mathrm{HCV}$ was acquired by risky sexual behavior, it is even more alarming that these persons have replicative HIV disease and therefore a high chance of transmission.

Seventy-seven percent of our patients received anti$\mathrm{HCV}$ treatment. This is highly promising as similar cohorts in chronically co-infected patients showed considerably low rates of treatment initiation [27] although HIV coinfection has the potential to aggravate HCV disease progression [12]. This is even more important as liver-related death has become the most frequent cause of non-AIDS-related death in the HIV infected population, mainly due to hepatitis $\mathrm{C}$ virus coinfection [28].

We found high rates of SVR in our cohort. With $69 \%$ in the on-treatment analysis SVR rates were clearly higher than in chronically co-infected patients, although most of our patients had unfavourable genotypes 1 and 4. This has also been described by other groups and the SVR rates are in concordance with the rates found in several European cohorts [17].Viral load drop at week 12, drop in hemoglobin levels at week 12, higher platelets and cART at the time of HCV diagnosis were significantly associated with SVR.

Most of the treated patients included in this analysis received additional ribavirin $(91 \%)$ to their treatment with pegylated interferon. An impact of this combination on treatment outcome can therefore not be drawn from these data. It rather shows that physicians stick to approved regimens in clinical practice as ribavirin is part of the standard-of-care in chronic $\mathrm{HCV}$ infection. However, the use of ribavirin for the treatment of acute hepatitis $\mathrm{C}$ has been an issue of discussion. In acute $\mathrm{HCV}$ monoinfection high rates of SVR have been reached with interferon or pegylated interferon monotherapy [29-31]. In most of the trials on coinfected patients additional ribavirin had been used, but in the German cohort patients treated with pegylated interferon alone achieved higher SVR rates than patients on pegylated interferon and ribavirin combination therapy, although the difference in SVR was not statistically significant and the number of patients was low [32]. Matthews et al. described comparable response rates in coinfected patients from the Australian cohort when treated with PEG/RBV compared to monoinfected treated with PEG alone [32]. The median time from diagnosis to treatment initiation was 12.6 weeks. This implies that a part of the patients were treated late regarding the course of acute $\mathrm{HCV}$ infection. Some of our patients were rather to be classified as early chronic than as late acute. Of note, our data come from a retrospective analysis and not from a prospective trial. Patients in this analysis were included since 2001, and knowledge and treatment decisions changed over time. This analysis rather reflects acute hepatitis $\mathrm{C}$ under real-life conditions. Accordingly, patients that were treated earlier had higher rates of SVR.

We found a high rate of spontaneous clearance in the untreated patients group (26\%). This confirms findings from a pooled analysis of several European cohorts [33]. However, HIV infection has been associated with high rates of HCV persistence, which, it has been hypothesized, is related to its impact on cellular immune function [34]. This was confirmed by Danta et al. who found that $95 \%$ of HIV-acute HCV coinfected patients developed persistent $\mathrm{HCV}$ infection [35]. The few patients that cleared HCV infection spontaneously had significantly higher ALT levels, were icteric and had higher CD4 cell counts. In our cohort, bilirubin and ALT levels were higher in patients who cleared HCV, and CD4 count was identical to the overall cohort, but no statistical significance could have been found. A real estimation of the spontaneous clearance rate in the natural course of $\mathrm{HCV}$ infection cannot be drawn from a dataset like ours. To date, clear-cut criteria for the likelihood of spontaneous clearance are not known. Most experts recommend to determine the drop of HCV RNA at week 4. If HCV RNA has dropped for 2 log or more, observation for spontaneous clearance might be reasonable in 4-weeks intervals up to week 12 . However, delaying the start of treatment for too long may eradicate the benefit of early treatment [16].In conclusion, our data 
describes the largest cohort of acute HCV infected patients so far. It is able to prove what has been postulated by several workgroups concerning the demographics and treatment outcomes in acute HCV and HIV coinfection. Especially in the setting of HIV infection, the physicians' awareness is needed to precociously spot $\mathrm{HCV}$ infections as early treatment leads to better results.

Financial disclosure: All participating centers have received a restricted grant from Essex Pharma GmbH.

Acknowledgements: We would like to thank the following persons for their contribution to this work: Ivanka Krznaric, Andreas Wienbreyer, Bianca Reisenweber, Daniela Behrendt, Christian Hoffmann, Christoph Schuler, Elke Lauenroth-Mai, Wolfgang Schmidt.

\section{REFERENCES}

1. Gilleece YC, Browne RE, Asboe D, Atkins M, Mandalia S, Bower M, Gazzard BG, Nelson MR. Transmission of hepatitis $\mathrm{C}$ virus among HIV-positive homosexual men and response to a 24-week course of pegylated interferon and ribavirin. J Acquir Immune Defic Syndr. 2005 Sep 1; 40(1): 41-6.

2. Vogel M, Bieniek B, Jessen H, Schewe CK, Hoffmann C, Baumgarten A, Kroidl A, Bogner JR, Spengler U, Rockstroh JK. Treatment of acute hepatitis $\mathrm{C}$ infection in HIV-infected patients: a retrospective analysis of eleven cases. J Viral Hepat. 2005 Mar; 12(2): 207-11.

3. Dominguez S, Ghosn J, Valantin MA, Schruniger A, Simon A, Bonnard P, Caumes E, Pialoux G, Benhamou Y, Thibault V, Katlama C. Efficacy of early treatment of acute hepatitis $\mathrm{C}$ infection with pegylated interferon and ribavirin in HIV-infected patients. AIDS. 2006 May 12; 20(8): 1157-61

4. Götz HM, van Doornum G, Niesters HG, den Hollander JG, Thio HB, de Zwart O. A cluster of acute hepatitis C virus infection among men who have sex with men-results from contact tracing and public health implications. AIDS. 2005 Jun 10; 19(9): 969-74.

5. van de Laar TJ, van der Bij AK, Prins M, Bruisten SM, Brinkman K, Ruys TA, van der Meer JT, de Vries HJ, Mulder JW, van Agtmael M, Jurriaans S, Wolthers KC, Coutinho RA. Increase in HCV incidence among men who have sex with men in Amsterdam most likely caused by sexual transmission. J Infect Dis. 2007 Jul 15; 196(2): $230-8$.

6. Luetkemeyer A, Hare CB, Stansell J, Tien PC, Charlesbois E, Lum P, Havlir D, Peters M. Clinical presentation and course of acute hepatitis $\mathrm{C}$ infection in HIV-infected patients. J Acquir Immune Defic Syndr. 2006 Jan 1; 41(1): 31-6.

7. Matthews GV, Hellard M, Haber P, Yeung B, Marks P, Baker D, McCaughan G, Sasadeusz J, White P, Rawlinson W, Lloyd A, Kaldor J, Dore GJ; Australian Trial in Acute Hepatitis C Study Group. Characteristics and treatment outcomes among HIV-infected individuals in the Australian Trial in Acute Hepatitis C. Clin Infect Dis. 2009 Mar 1; 48(5): 650-8.

8. Marcus U, Voss L, Kollan C, Hamouda O. HIV incidence increasing in MSM in Germany: factors influencing infection dynamics. Eur Surveill. 2006 Sep; 11(9): 157-60.

9. van der Laar T, Pybus O, Bruisten S, Brown D, Nelson M, Bhagani S, Vogel M, Baumgarten A, Chaix ML, Fisher M, Gotz H, Matthews GV, Neifer S, White P, Rawlinson W, Pol S, Rockstroh J, Coutinho R, Dore GJ, Dusheiko GM, Danta M. Evidence of a Large, International Net- work of HCV Transmission in HIVPositive Men Who Have Sex With Men. Gastroenterology. 2009 May; 136(5): 1609-17

10. Gebo KA, Diener-West M, Moore RD. Hospitalization rates differ by hepatitis $\mathrm{C}$ status in an urban HIV cohort. J Acquir Immune Defic Syndr. 2003 Oct 1; 34(2): 165-73.

11. Bica I, McGovern B, Dhar R, Stone D, McGowan K, Scheib R, Snydman DR. Increasing mortality due to endstage liver disease in patients with human immunodeficiency virus infection. Clin Infect Dis. $2001 \mathrm{Feb}$ 1; 32(3): 492-97.

12. Benhamou Y, Bochet M, Di Martino V, Charlotte F, Azria F, Coutellier A, Vidaud M, Bricaire F, Opolon P, Katlama C, Poynard T. Liver fibrosis progression in human immunodeficiency virus and hepatitis $C$ virus coinfected patients. The Multivirc Group. Hepatology. 1999 Oct; 30(4): 1054-8.

13. Danta M, Semmo N, Fabris P, Brown D, Pybus OG, Sabin CA, Bhagani S, Emery VC, Dusheiko GM, Klenerman P. Impact of HIV on host-virus interactions during early hepatitis $C$ virus infection. J Infect Dis. 2008 Jun 1; 197(11): 1558-66.

14. Graham CS, Baden LR, Yu E, Mrus JM, Carnie J, Heeren $\mathrm{T}$, Koziel MJ. Influence of human immunodeficiency virus infection on the course of hepatitis $C$ virus infection: a meta-analysis. Clin Infect Dis. 2001 Aug 15; 33(4): 562-69.

15. Greub G, Ledergerber B, Battegay M, Grob P, Perrin L, Furrer H, Burgisser P, Erb P, Boggian K, Piffaretti JC, Hirschel B, Janin P, Francioli P, Flepp M, Telenti A. Clinical progression, survival, and immune recovery during antiretroviral therapy in patients with HIV-1 and hepatitis C virus coinfection: the Swiss HIV Cohort Study. Lancet. 2000 Nov 25; 356(9244): 1800-05.

16. Vogel M, Rockstroh JK. Treatment of acute hepatitis $C$ in HIV infection. J Antimicrob Chemother. 2010 Jan; 65(1): 4-9.

17. Vogel M, Dominguez S, Bhagani S, Azwa A, Page E, Guiguet M, Valantin MA, Katlama C, Rockstroh JK, Nelson M. Treatment of acute HCV infection in HIV-positive patients: experience from a multicentre European cohort. Antivir Ther. 2010; 15(2): 267-79.

18. 1993 Revised classification system for HIV infection and expanded surveillance case definition for AIDS among adolescents and adults. MMWR Recomm Rep 1992; 41(RR-17):1-19.

19. Rauch A, Rickenbach M, Weber R, Hirschel B, Tarr PE, Bucher HC, Vernazza P, Bernasconi E, Zinkernagel AS, Evison J, Furrer H. Unsafe sex and increased incidence of hepatitis $C$ virus infection among HIV-infected men who have sex with men: the Swiss HIV Cohort Study. Clin Infect Dis 2005 Aug 1; 41(3): 395-402.

20. Ghosn J, Deveau C, Goujard C, Garrigue I, Saichi N, Galimand J, Nagy Z, Rouzioux C, Meyer L, Chaix ML. Increase in hepatitis $C$ virus incidence in HIV-1-infected patients followed up since primary infection. Sex Transm Infect. 2006 Dec; 82(6): 458-60.

21. Mattapallil JJ, Douek DC, Hill B, Nishimura Y, Martin M, Roederer M. Massive infection and loss of memory CD4 $\mathrm{T}$ cells in multiple tissues during acute SIV infection. Nature. 2005 Apr 28; 434(7037): 1093-97.

22. van de Laar TJ, Paxton WA, Zorgdrager F, Cornelissen M, de Vries HJ. Sexual transmission of hepatitis $C$ virus in human immunodeficiency virus-negative men who have sex with men: a series of case reports. Sex Transm Dis 2011 Feb; 38(2): 102-4.

23. Matthews-Greer JM, Caldito GC, Adley SD, Willis R, Mire AC, Jamison RM, McRae KL, King JW, Chang WL. Comparison of hepatitis $\mathrm{C}$ viral loads in patients with or without human immunodeficiency virus. Clin Diagn Lab Immunol. 2001 Jul; 8(4): 690-94. 
24. Giraudon I, Ruf M, Maguire H, Charlett A, Ncube F, Turner J, Gilson R, Fisher M, Bhagani S, Johnson M, Barton $\mathrm{S}$. Increase in diagnosed newly acquired hepatitis $\mathrm{C}$ in HIV-positive men who have sex with men across London and Brighton, 2002-2006: is this an outbreak? Sex Transm Infect. 2008 Apr; 84(2): 111-5.

25. Urbanus AT, van de Laar TJ, Stolte IG, Schinkel J, Heijman T, Coutinho RA, Prins M. Hepatitis C virus infections among HIV-infected men who have sex with men: an expanding epidemic. AIDS. 2009 Jul 31; 23(12): F1-7.

26. Ghosn J, Deveau C, Goujard C, Garrigue I, Saichi N, Galimand J, Nagy Z, Rouzioux C, Meyer L, Chaix ML. Increase in hepatitis $C$ virus incidence in HIV-1-infected patients followed up since primary infection. Sex Transm Infect. 2006 Dec; 82(6): 458-60.

27. Baumgarten A, Hofmann C, Obermeier M. Hepatitis C coinfection in HIV-infected patients - evidence for considerable undertreatment. European AIDS Conference 2009; Cologne, Germany: Poster PE13.2/9

28. Weber R, Sabin CA, Friis-Møller N, Reiss P, El-Sadr WM, Kirk O, Dabis F, Law MG, Pradier C, De Wit S, Akerlund B, Calvo G, Monforte A, Rickenbach M, Ledergerber B, Phillips AN, Lundgren JD. Liver-related deaths in persons infected with the human immunodeficiency virus: the D:A:D study. Arch Intern Med. 2006 Aug 14-28; 166(15): 1632-41.

29. Gerlach JT, Diepolder HM, Zachoval R, Gruener NH, Jung MC, Ulsenheimer A, Schraut WW, Schirren CA, Waechtler M, Backmund M, Pape GR. Acute hepatitis C: high rate of both spontaneous and treatment-induced viral clearance. Gastroenterology. 2003 Jul; 125(1): 80-8.

30. Jaeckel E, Cornberg M, Wedemeyer H, Santantonio T, Mayer J, Zankel M, Pastore G, Dietrich M, Trautwein C, Manns MP; German Acute Hepatitis C Therapy Group. Treatment of acute hepatitis $\mathrm{C}$ with interferon alfa-2b. N Engl J Med. 2001 Nov 15; 345(20): 1452-57.

31. Wiegand J, Buggisch P, Boecher W, Zeuzem S, Gelbmann CM, Berg T, Kauffmann W, Kallinowski B, Cornberg M, Jaeckel E, Wedemeyer H, Manns MP; German HEP-NET Acute HCV Study Group. Early monotherapy with pegylated interferon alpha-2b for acute hepatitis $\mathrm{C}$ infection: the HEP-NET acute-HCV-II study. Hepatology. 2006 Feb; 43(2): 250-56.
32. Vogel M, Nattermann J, Baumgarten A, Klausen G, Bieniek B, Schewe K, Jessen H, Boesecke C, Rausch M, Lutz T, Fenske S, Schranz D, Kümmerle T, Schuler C, Theisen A, Mayr C, Seidel T, Rockstroh JK. Pegylated interferonalpha for the treatment of sexually transmitted acute hepatitis C in HIV-infected individuals. Antivir Ther 2006; 11(8): 1097-101.

33. Matthews GV, Grebely J, Hellard M, Yeung B, Marks P, Rawlinson W, Kaldor J, Dore G, ATAHC Study Group et al. Differences in early virological decline in individuals treated in the Australian Trial in Acute HCV suggest a potential benefit for the use of ribavirin. EASL conference 2010, Vienna, Austria, oral presentation.

33. Azwa A, Vogel M, Bhagani S, et al. The natural history of acute hepatitis $\mathrm{C}$ (AHC) in HIV co-infected individualsa European collaborative study. In: Abstracts of the Eleventh European AIDS Conference, Madrid, Spain, 2007. Abstract PS8/5.

34. Thomas DL, Astemborski J, Rai RM, Anania FA, Schaeffer M, Galai N, Nolt K, Nelson KE, Strathdee SA, Johnson L, Laeyendecker O, Boitnott J, Wilson LE, Vlahov D. The natural history of hepatitis $\mathrm{C}$ virus infection: host, viral, and environmental factors. JAMA. 2000 Jul 26; 284(4): 450-6.

35. Danta M, Semmo N, Fabris P, Brown D, Pybus OG, Sabin CA, Bhagani S, Emery VC, Dusheiko GM, Klenerman P. Impact of HIV on host-virus interactions during early hepatitis $C$ virus infection. J Infect Dis. 2008 Jun 1; 197(11): 1558-66.

Received: September 27, 2010 / Accepted: March 15, 2011

Address for correspondence:

Axel Baumgarten

Medical Center for Infectious Diseases (MIB)

Seestr. 13

13353 Berlin

Germany

Tel.: $\quad+49-30-451988940$

Fax: $\quad+49-30-4519889424$

E-mail: axelbaumgarten@t-online.de 